\title{
Trading time and space in grassroots negotiations in a Brazilian mining district
}

Participatory governance has been used to direct public budget and policy priorities. Grassroots politics also offer democratic pathways for negotiations over permits for businesses such as mining. In this paper, I focus on notions of time in policy-meetings between a mining company, the affected community in the district of Miguel Burnier, Brazil, and mediators between them members of a municipal council for cultural heritage. I used ethnographic data to investigate whether participatory councils could abridge temporalities and offer a compromise. While the company offered improvements in quality of life in an uncertain future and the council needed to preserve local cultural heritage, residents suffered from pressing problems in the present: depopulation, pollution, and unemployment. My findings show that participation could not solve residents' socio-economic problems efficiently, for these same problems affected their ability to voice concerns and wait for compensations. Relaxing immediate economic pressures improves the process of participation.

(mining, time, participation, negotiation, heritage, policy councils, Brazil, Ouro Preto). 


\section{Introduction}

Imagined positive pasts and futures have been highlighted as an instrument that could allow citizens to create a more positive perception of an insufficient present (Nielsen 2011). This article will address the asymmetrical impact of different temporalities on participatory practices in small cities, where civil society is not highly organized and groups of people may have competing interests. I explore conflicting notions of past, present and future in negotiations between a mining company, residents of the town of Miguel Burnier, and mediators from the Municipal Council for the Preservation of Cultural and Natural Patrimony, which I will refer to as the Council throughout this article. The company wanted to extend mining activity in Miguel Burnier, to the detriment of the local population, and the Council had to cast its vote about the expansion, taking into account the compensation offered by the company to the affected community. Both the Company and the Council imagined the past and future of Miguel Burnier (through cultural heritage) while residents, facing pressing needs in the present, had their own views about the place they inhabit. I will investigate whether participatory practices allowed residents of Miguel Burnier to improve their actual and perceived living situation, and how participation could be improved to function as a tool in the democratic process.

According to Nielsen’s investigation about house building in Mozambique (2011, 2014), perceived time is not always linear. The future may organize the present by giving people a sense of meaningfulness. Meaning, in this case, is not related to obtaining success, but to the value in trying, even when failure is expected (Nielsen 2011). Also on house building, Lea and Pholeros (2010) discuss houses built with pipes that do not connect with any form of sewage. Rather than being a plan for a future, such pipes are already efficient in the present offering the government an aesthetical seal of a house that looks 'right' (as discussed in Larking 2013: 335). Negotiations like the ones in Miguel Burnier thus do not necessarily need to offer immediate compensations to be 
deemed efficient. Promises that focus on the future (or past) could already ameliorate a chaotic present. Negotiations could also offer a sense of meaningfulness to residents, especially valuable if bonding residents to each other, even if desired outcomes are not achieved. However, previous anthropological research has also discussed the social limits of imagining another time in the face of present decay (Souza 2010). The options for deprived groups have been argued to be "material and proximate” (Appadurai 2013, 188) because the poor live in an “eternized present”, lacking the chance to plan for the future when busy with the everyday needs tormenting them (Souza 2010: 51, Appadurai 2013: 188). I examine time horizons during negotiations in Miguel Burnier, a location characterized by depopulation, a deficit in infrastructure, and industrial pollution. I consider the need for a "stronger emphasis on the temporal dimensions of governance" (Raco et al. 2018: 1176), which is still sorely lacking.

Most of the existing studies dealing with participation in Brazil have looked at larger cities, such as Rio de Janeiro, São Paulo, Belo Horizonte, or Porto Alegre (Avritzer, 2006, 2010, 2012b; Holston 2008), or looked at pioneering practices, such as participatory budgeting (Avritzer 2006, 2012a), participatory master plans (Avritzer 2010), and health councils (Cornwall 2008; Cornwall \& Shankland 2013; Guareschi \& Jovchelovitch 2004). The difference in the case of smaller municipalities is that participation did not emerge from a "strong presence of social movements” as it did in larger cities such as Recife (Koster \& Nuijten 2012). Rather, local governments promoted it as a condition to access public funds (Koster \& Nuijten 2001: 176).

Studies in Brazil have also focused mainly on the meaning of public sphere and social representation (Avritzer \& Costa 2004; Jovchelovitch 1995), political culture (Cornwall \& Shankland 2013), and the impact of participation on policies (Avritzer 2012a). Political and anthropological research focusing on sustainability and cultural heritage discourses have increased interest in the issue of temporality in policy negotiations, as both promote the 
imagination of the past or future (Raco et al. 2008). The investment in cultural heritage, though treasuring a past, is usually associated with future outcomes, such as identification of residents with a place (Silverman 2002: 884), and material gains, for example with growth in tourism (Caust and Vecco 2017). When mining businesses invest in the preservation of cultural heritage, the pendulum movement "of nostalgia and longing” (Harms 2011: 91) weakens the focus on present problems caused by mining exploration (for example pollution). The key question here is how to measure outcomes across time and space. Finally, government employees, mining company staff, and the affected community have different levels of wealth and power (networks, secure housing and job, access to the legal system). As a result, the effort required to participate in policy-councils is different, with the poor having to expend greater effort to participate in comparison with other groups, and yet, the impact of participation return, such as achieving public service delivery, is high for the poor (Bertorelli et al. 2017).

In what follows, I describe Miguel Burnier and its pressing problems of depopulation and pollution and discuss the role of participatory meetings in policy-making in Brazil and especially in a small town context. I then examine offers made by the mining company to the affected community, where I address temporality in policy-making and the ability of the Council in mediate and compromise time-horizons. In the conclusion, I discuss which initial conditions need to be observed for effective participation.

\section{Miguel Burnier}

Miguel Burnier is one of the thirteen districts that compose the municipality of Ouro Preto (Figure 1). Located $40 \mathrm{~km}$ away from the downtown area of Ouro Preto, where most of the 74.659 inhabitants live (IBGE 2017), only a few hundred people live in Miguel Burnier, a place 
renowned for its mineral deposits. Despite its demographic insignificance and geographical remoteness, the district creates significant tax revenue because of its industrial capacity. The area has seen a number of different companies extract iron ore for steel production since the early $19^{\text {th }}$ century (Penha 2012: 13).

[Please insert Figure 1 here]

The families, and later companies, that occupied the area for mining since the 1700 s allowed for the growth of the local economy. The first families built churches in their vicinity, with some of the oldest from 1726 (Neves 2012: 66). Companies arriving later built workers' villages - with houses, a football field, and urban amenities, as is expected in one-company towns, where the social and commercial life of the city is often entangled with company businesses. These improvements reflect the vigour of the mining sector in the area, and as this small district grew in the 20th century, it is an exception to the typical rural-urban migration movement throughout Brazil.

The district had two important mining companies; Wigg (1893-1969) and Barra Mansa (1969 -1996). Most of its inhabitants left, however, when Barra Mansa ceased its iron and gravel mining activities (Figure 2) and, with this rapid depopulation, the district has been falling into a state of urban decay since 1996. When a new mining company started to work in the district in 2004, the expectation of the remaining residents was that it would reverse the state of decay (houses falling apart, depopulation, and lack of public services), as was expected from new businesses arriving in Miguel Burnier. However, the company did not. Instead, mining works expanded closer to the urban nucleus, where the remaining residents lived, and the company 
mainly hired trained workforces from neighbouring towns who commuted to work instead of hiring people from the community.

[Please insert Figure 2 here]

However, the same mining company that aimed to expand mining activities closer to the remaining residents also supported the preservation of cultural heritage. The use of heritage as compensation for mining is differently perceived by residents, because "the veneration of memorials or ruins implies a distancing that is usually alien to those who experience those sites as part of their daily lives” (Gordillo 2009: 44). For ordinary residents, to praise the past may give a sense of worth to buildings and achievements of former inhabitants to the detriment of current ones (Gordillo 2013: 334; Heathcott 2013; Reed 2002: 138). Current residents than prioritize other amenities, such as improving air and water quality and stopping depopulation. Looking at the interaction between mining, heritage, and residents is thus looking at the complex interaction between past, present, and future, and the material effects of time (Harms 2011: 93).

Investing in cultural heritage is however common in that region of Minas Gerais. Mining activities in the area date back to colonial years. Mining wealth produced an impressive baroque architecture and Ouro Preto's main district has been a UNESCO World Heritage Site since the 1980s. The relationship between mining and heritage is thus, most of the time, one of reciprocity: previous mining allowed people to build expensive buildings that are now preserved. The maintenance of such structures is expensive and new mining companies often negotiate industrial permits by offering the upkeep of cultural goods as compensation.

In the case of Miguel Burnier, its urban nucleus is not a heritage site, but some select buildings have been restored or examined for preservation. Such historic importance poses a limit 
to the expansion of mining businesses in the area. Yet, the preservation of those monuments requires financial investments, and mining is the only industry in the area. The question here is how close the exploration of minerals can be from the remaining houses and residents, and whether the upkeep of buildings could bring an increase in quality of life for residents. Recent investments in cultural goods brought with them promises, such as the creation of jobs in the cultural and tourism sector. However, the tourism economy is not only far off amidst current mining activities, but also, it is not necessarily more stable than mining. There is a palpable level of instability in central Ouro Preto, with residents relying on precarious jobs and informal housing (reference anonymized).

In Miguel Burnier, residents have thus been uncertain about heritage promises and would prefer more immediate compensation from the company, or they would instead negotiate their own removal. Negotiations would be mediated by the Council. Members of the Council, on the other hand, have their own agenda: having to guarantee that preserved monuments are not threatened by either mining or mass eviction. The company, the residents of Miguel Burnier and the Council met in grassroots negotiations in search of a common solution.

\section{Participatory city planning in Brazil}

The discussions between the company, the affected community, and the Council follow a tradition of bottom-up planning in Brazil and other Latin American countries, which gained traction, especially in the late 1980s after the end of military dictatorships (Lombard 2013). This was also a period of neoliberal economic policies in Latin America to stabilize economies threatened by high inflation. Diminished state spending capacity was accompanied by participatory mechanisms, hoping to endow economies with resilience through democratic governance (Rodrik 2006: 985). 
National and international organizations supported local governments to implement participatory decision-making on a broad scale (Guareschi and Jovchelovitch 2004: 312).

Brazil, which in the 1950s and 1960s was famous for its modernist state-centred city planning, soon after became an international example of participatory planning when new norms (Brazil’s 1988 Constitution and the 2001 City Statute) helped develop new ways in which nonstate actors could participate in city governance (Caldeira and Holston 2005). More specifically, the 1988 Constitution is considered a citizens' constitution because suffrage rights were unrestricted, municipalities gained more political autonomy in relation to the national state, the politics of urban development addressed the social function of the city, and cities with more than 20,000 inhabitants needed to write a master plan to determine their urban development. Those elements about citizenship and citizens' rights in the city later culminated with the creation of the City Statute (2001) that regulated civilian participation in the democratic making of the city (Andrade dos Passos 2010: 85).

However, the results and processes of new city planning practices are still indeterminate and contested throughout Brazil and beyond. It remains unclear, for example, how "community and belonging” (Hughes 1998: 7) may still look to the state to guarantee interconnection among citizens (Albert 2016: 13). Marks and Bonnin (2010) argued that "while non-state actors are encouraged to participate (...) they are not always adequately supported in their attempts. Nodal actors may even compete with one another" (2010: 59). Problems and expectations about "the social” are slowly being investigated by studies such as this one, looking at the dynamics of new spheres of participation - how communities organize themselves to address common problems and how they may cooperate with each other and the state. 


\section{Participatory councils in Ouro Preto}

Participatory policy councils are collegiate groups that exist to advice or direct public administration in diverse areas, such as social assistance, health, or transportation. In the case of municipal councils on cultural heritage in Minas Gerais, where Ouro Preto is located, a regional law (known as ICMS Cultural) establishes conditions for municipalities to access cultural funds, such as having patrimonial education and a municipal council on cultural heritage. Therefore, about $70 \%$ of the 853 municipalities in Minas Gerais possess a municipal council for cultural heritage. In comparison, the southern region of Brazil including Porto Alegre, a city famous for its participatory budgeting practices, has only approximately $8 \%$ of municipalities having such a forum (IBGE 2012: 83).

The need to have heritage councils in Minas Gerais means that spheres of participation will not always be motivated by specific social movements. In Ouro Preto's Council, there were 11 Council members in 2013, despite the 16 total seats. Of the 11 members, only two were representatives of residents' associations. The remaining members were government technicians (three); two representatives in the federal and state level of the Institute for the Historic and Artistic Patrimony (IPHAN), one representative of the university, and one representative of the local art school. Despite the limited participation from all segments of civil society, decisions taken by the Council are binding rather than merely suggestive. There are various reasons for the low level of participation, including the fact that the meetings take place during working hours and that many residents prefer avoiding public confrontations, as I will discuss. 


\section{Negotiations}

An initial community-company-council discussion about the expansion of three local mines (one of them expanding to within a short distance from residential areas) took place in a classroom in Miguel Burnier's only school in June 2013. Residents (an age-diverse group of mainly unemployed citizens) made up half of the participants and were joined by the Council. They were accommodated in pupils' chairs in the middle of the room. The negotiators from the prefecture (the vice-mayor among them) took up positions on the side of the room, while the mining company representatives stood in front. This positioning in the room not only grouped the parties separately, but it also indicated the expected leadership.

The company began its presentation by talking about initiatives to improve the quality of life in the community: renovating the school, improving access to the church, setting a green belt to separate industrial from residential activities, creating a football field and renovating the sports center, improving the facilities at the health center, and providing free professional courses to train residents as tailors, painters, carpenters, and manicurists. After the presentation of possible upcoming improvements, the vice-mayor announced he was looking forward to a partnership with the company that would benefit the community.

The optimistic presentation failed to address salient points, which the community promptly highlighted. The leader of the community said, “There were trees at the back of Teresa's house, they were felled, and you now talk about a green belt?” That leader and others added that the green belt could please the eye and diminish dust problems, but it would not suffice to diminish noise. Another point of contention was the fact that the community was diminishing in size and a new football field was a reminder of this, as it was now a challenge to find enough adults to play. The improvement of the health centre was also discussed and connected to depopulation and lack 
of doctors. Similarly, although the school needed a coat of paint on the walls, the problems ran deeper. For example, while new computers had been installed, the school lacked information technology teachers and Internet connection.

Regarding professional courses, the company demanded a minimum number of about 20 people per class, which raised further concerns. Also, to whom would the manicurists, painters, or house builders cater to in a shrinking community? Lastly, a woman pointed out that while she would like to learn a profession and work, there was no nursery where she could leave her children.

The controversies showed that even if improvements could be made, plans were still at odds with the district's main problem: population decline. Depopulation became an even greater threat when the company released the results of a survey they had conducted, which among other questions asked if residents wanted to leave their homes. The questionnaire found that $64 \%$ of 380 residents wanted to leave Miguel Burnier. Publicly releasing those numbers generated great bewilderment. The community leader remarked that, when the company announced they would conduct a survey, they had declared that if 55\% of respondents wanted to leave their houses, the company would try to buy their properties. The company, however, denied this; they claimed the survey was only designed to get to know the population and their demands. However, the leader replied that if the questionnaire was created to get to know the population better, the company could also release other results to try to understand why people replied that they wanted to leave. He explained,

At my house, a surveyor asked my mum what bothered her about the company. Before she answered, the surveyor was already ticking nothing, 'right?' Then I said, let me explain to 
you, mum, when the dirty water in the rainy season prevents you from washing the clothes that are mud coloured, the company causes this. When you go out in the middle of the trucks with dust and mud and noise, the company creates this (...) if the company wants to release the results, let's release the whole questionnaire to see the reason why people would like to leave (Community leader, 2013).

Another resident added, "asking if people would like to go to heaven is different from asking if people would want to die.” In his opinion, the results were announced as if people "want to die," that is, they want to leave the area; when in fact they mentioned problems in the area and that they "want to go to heaven," they want to live in better conditions. But in order "to go to heaven, they have to die;" that is, to live in a better area, they need to leave their houses, as most of them did not feel hopeful that a good life was possible in the middle of mining activities.

The questionnaire, as an instrument of speculation - whether residents would be willing to sell their houses - failed to assess present scarcities, which would explain why residents would be willing to sell their houses. Conflicts about what makes a place worth living in and the ability of policies to mediate current demographic and infrastructure shortages reached a crescendo and while people reaffirmed their interest in leaving, they made the reasoning behind this interest clear. However, the solution to their complaints offered by the company remained opaque, as offered improvements did not target various inconveniences such as depopulation, heavy vehicle traffic or issues revolving around air, noise, and water pollution. On the contrary, the company's expansion would potentially further increase such problems.

In addition, the release of the number of people willing to sell their properties affected residents' will to bargain for improvements. The company tried to diminish expectations that it 
would buy houses but did not deny the possibility of buying a few. It was legally impossible for the company to buy all residents out and destroy homes, as there are protected monuments in the area whose surroundings should be kept, a concept known in Brazil as "ambience" (Ribeiro 2007: 40). However, some properties were already under negotiation, e.g. houses close to the main road.

The community leader's situation provides a great insight into the dilemma faced by the community. Although he is one of those residents who would like to leave the district and sell his house to the company, he is nevertheless negotiating improvements. He explained his torment to me, as he was uncertain about persuading his neighbours to stay while he personally would like to leave (which would make him a traitor in their eyes). He is equally uncertain about staying and fighting for improvements, as his neighbours could be the ones leaving. Finally, improvements may be delayed, may be insufficient, or may never come, and he and his fellow residents may feel foolish about false hopes and lost opportunities if they stayed. This situation highlights the importance of the Council as a negotiator. The Council could increase trust on the receiving side that services promised would be honored (Barbalet 2009: 371).

If residents do not see a future for the district, why would they try to remain there? However, if they envision hope (that amenities can be negotiated according to residents' claims and that improvements will follow), it might be worthwhile to stay and negotiate developments. The prefecture could take the role of abridging time horizons in policy-making, as the democratic representative of the people. However, the company pays high taxes to the prefecture and, as in other development projects in Brazil, residents perceive company and government to be on the same side (Koster and Nuijten 2012: 182). As the expansion of mining activity was dependent on the assessment of the Council, it could increase the likelihood that the company's promises meet residents' expectations and take concrete form, making promises more tangible. The Council 
carries with it the credential of representing different sectors of civil society, and it can potentially remedy power asymmetries between the company (and prefecture) and residents.

However, the Council centres its efforts on cultural preservation. Investments in cultural heritage (the restoration of buildings and archives) had already been offered by the company to the district in order to obtain mining licenses in the recent past and these did not satisfy the community. As a result, there were reasons for residents' mistrust of a council dealing with cultural heritage. However, the community felt they needed a mediator, since the population of residents, composed of elderly citizens, children, and unemployed and unskilled adults lacked the knowledge about what was at stake. For example, the company did not explain the expansion of its business in terms of how many years this activity would last, nor in terms of financial gain for the company (or the municipality in tax collection).

In the following section, I discuss how the company's representatives tackled vagueness over environmental, social, and economic impact with equally vague concepts such as "selfesteem" and "quality of life" for residents. While there was no clear definition of these futureoriented concepts, the company claimed those were improvements brought by their investments in cultural heritage.

\section{6. “Here is the deal”: self-esteem and life quality}

The link between Brazilian public policies and self-esteem is not new: some political programs intended to increase the self-esteem of specific groups have already been discussed in anthropological literature that focuses on Brazil (Gledhill 2013). In the case of Ouro Preto (and other cities with a cultural appeal, such as Salvador and Olinda), the connection between selfesteem and cultural heritage is strong, as heritage could offer a 'material and symbolic assistance 
for identity construction' (Aykan 2013: 384), thus increasing the self-esteem of residents. However, the meaning of cultural heritage was not identified by residents but designated by government experts (Chuva 2009). The population in Ouro Preto, for example, did not decide on the themes of museums or on specific sites to be preserved. They were rather invited to participate in existing cultural projects to feel integrated into their city and improve the quality of their lives.

The problem with the combination of such idealized standards of self-esteem and culture with participatory meetings, as Gledhill (2013) states, is that "rituals of participation have more power than top-down measures alone to create a sense of grassroots 'ownership' of policies” (Gledhill 2013: 121). Self-esteem and life-quality may only be expectations, open terms empty of concrete actions, connected to imposed cultural standards, and far removed from present needs that are necessary for a better life, yet participation can inspire a belief in a better life in the future (Abram \& Weszkalnys 2013: 12).

Residents and the company used terms such as "self-esteem" and "life-quality" without ever understanding what these meant to the other side, and Council members had to decide which definition to follow. Miguel Burnier residents understood improvements in self-esteem as connected to better infrastructure, re-population, and employment. Life quality and self-esteem featured as the company's deal for the community, including supporting cultural festivals, museums, and restoring historical documents, activities aimed at "rescuing $(\ldots)$ the pride to be Burnierense by understanding the community as a cultural reference", as a member of the company explained. The community leader reacted to such list of "social investments" by saying that more than 1 million Brazilian Reais (about USD 300.000) were spent to restore the train station (Figure 3) to improve the "quality of life" for residents. However, the station, though furnished and equipped with books to be a local library, was closed due to a lack of staff. 
For one councillor, investments focused on the cultural aspects of the city were not only fragmented but also paradoxical, given the company’s survey that suggested that most residents would prefer to leave the area. Would they now stay despite the unfriendly conditions brought by mining activities for the sake of their pride in being part of that cultural heritage? In her words, "It is very easy to say: 'look how beautiful your church is', but around the church, there is dust and noise and a series of social problems.” The paradox for that Council member was not the creation of cultural and pedagogic actions to change the existing negative perceptions of the space, but having those investments while living conditions remained the same or risked worsening if mining expansion was approved. However, being a Council dealing with cultural heritage, to reject the company's proposals to increase self-esteem was also to reject some preservation actions, and Council members had internal conflicts and thus delayed making decisions.

Nearly six months of monthly meetings concluded without concrete ideas of how expanding mines might worsen living conditions in the village, how long such activities would last, and how improving standards of life quality and self-esteem could address residents' daily concern about noise and dust. To end these inconclusive discussions, the Council decided to form a commission to visit the district. Three Council members from different backgrounds formed the commission: architecture, community representation, and environmental engineering. When the visit took place, I accompanied the group.

\section{The commission}

Arriving in Miguel Burnier, or at the "Mine of Miguel Burnier" (as announced by the welcoming billboard when reaching town) there was a gate to control access and check visitors' identity, provoking a heated discussion among the commissioners about the road, its ownership and the company’s right to request identifications at the entrance of a village. 
At the centre of Miguel Burnier, standing out from a landscape of run-down houses lies the train station, newly restored, looking ageless in the middle of a decayed city centre. Its recent restoration (in 2012) in an environment of deterioration, but also its silence without passengers or trains, and its cultural centre that remained closed due to a lack of staff added to an unreal atmosphere of preserved buildings absent of life (Figures 3 and Figure 4).

[Please Insert Figures 3 and 4 here]

From the train station, the commission divided into different groups. The architect and engineer looked for traces of mining effects such as erosion and dust in the area, while the councillor with a community leadership background and I spoke to the leader of the district's community association.

While we toured the train station, the community leader explained that to many residents, the restoration of the train station was controversial. Rather than inspiring self-esteem, as promised at the time of restoration, it reminded residents that only some buildings were praiseworthy, and he asserted that the building had a sense of worthiness residents did not feel in their own lives. Thus, to him, the current negotiation between the company and residents through a Council focused on city preservation was dangerous. Yet, he remarked community interests needed a mediator. As an example, he mentioned that the company promised amenities for the community, but at the same time bought some houses, so the families that lived in those houses moved to other cities. The houses, he explained, were located near the road used for mining traffic and concerns for the safety of the residents had justified the purchase. However, he stated that the company had created the risk in the first place, through heavy trucks on that road. For the 
company, safety meant removing the people, rather than removing the cause of danger. The departure of a few families in a location of only 380 residents diminished the belief that urban amenities, such as preservation projects, could have positive effects on a shrinking community.

That leader described the local situation of decay by explaining that when the company Barra Mansa left the area in 1996, most of the then 1600 residents also decided to leave. Among those who stayed, there were several cases of suicide, because people were dependent on the company. Often workers’ rents along with their grocery, electricity or pharmacy bills had been deduced from their salaries, as the company owned all services in the district.

The conversation with the community leader made clear the sense of loss the residents felt when businesses departed, illustrating that residents' expectations of a better life were related to work and the social and economic structure around it. The proposal of a better life related to the preservation of cultural heritage, as exemplified by the restoration of the train station, flies in the face of such accounts. Moreover, although the company is not at the centre of the district's life as others had been historically, and so inhabitants appear not to rely on it as much as they used to, it remains difficult for residents to argue aggressively with the company for improvements. The company still provides work for a few residents and holds out the promise of work for a few others. As a result, although the company's offers do not meet residents' expectations, they have little choice but to take what is offered. The community leader reported his sense of reservation during negotiations:

They make the community fight and the community fights against itself. Some people want to leave, while others would rather stay. So they give us the rope and with that, we hang ourselves. Some do not want to fight the company because their kids work there, some 
people want to leave the area, some people want to stay and improve the area, the community association works for whose interest? (Community leader, 2013)

The meaning implied here is that tools for negotiation exist in a context where those who rely on the state and the company the most must fight against them. In addition, the community has varied and competing interests, lacks complete information of the options available to them, and feels the threat of losing existing or potential jobs and housing improvements. The alternative of no negotiation at all, however, could mean slowly letting the district cease to have a population. Residents would leave of their own accord; and in this case, they would not even receive financial compensation when abandoning their houses.

\section{Making decisions while avoiding confrontations}

The Council had to reach a decision on the company's expansion and also had to decide about the demolition of houses bought by the company that were close by a road. Regarding house demolition, the council agreed to abstain from the matter.

The unwillingness of Council members to decide on the demolition of the houses followed a previous decision when they abstained from debating the list of improvements that was offered by the company to the community (including establishing a football field, professional courses, renovating buildings, among other amenities). In the final meetings, Council members assumed an apologetic position and abstained from making key decisions. They had accumulated knowledge about the community, nevertheless, alongside that, they were aware of economic and political interests at stake, which explains their refusal to debate or decide on actions in parallel to the 
mining expansion in an effort to avoid being perceived as a nuisance by the company (and the government). Even though many Council members were public servants, thus enjoying permanent positions, one's political engagement can influence the likelihood of receiving promotions or securing preferred areas of work. To avoid repercussions in their career (known in Brazil as 'going into the freezer', ir pra geladeira) such as being precluded from key activities and decisions, participants often announced in what capacity they were voicing an opinion: as the technical expert, as the resident, or as a Council member in a volunteer political role. By positioning themselves as different entities, Council members not only assumed multiple roles they have in the city but also hoped to avoid being seen as an employee. They remained unsure if that strategy would be efficient and did not want to be singled out as stakeholders of decisions that could impede the company and prefecture's interests.

Representatives of the mining company took turns attending meetings and always spoke on behalf of the company. Speaking as a group or "as though one's personality were a passive recipient of the bureaucratic functioning” (Sennett 1976: 331) had different consequences for those participants. The company was always addressed as a company rather than by the names of the officials present, and feelings of a nuisance to the community could, in this case, be diffused. Residents (mainly represented by the community leader) were also afraid to express their personal views about this important economic project, as the mining company was the only source of employment and investments in the area. Residents, who then tried to avoid directly contradicting the company's interests, approached me to advocate on their behalf: "you should make a point, bargain, you are the only one free here.” However, though I was in a privileged position in comparison with my informants - as I did not have housing or job interests at stake - any confrontation from my side could generate collateral damage for residents or Council members who were associated with me (reference anonymized). 
This evolving perception of threat was present throughout negotiations. One of the meetings, for example, started with a letter from the Municipal Administrator for the Secretariat of Culture and Patrimony stating his support to mining expansion because of its economic importance. The administrator, however, was the direct supervisor of some Council members who were then intimidated to cast a vote that could be opposing to the revealed view of their boss. The prosecutor's office [1] in town also manifested concern about negotiations taking place, also by sending letters to the Council, but in this case, being against any hurried decisions that could be costly to residents. To avoid conflicts with the company, the government, and prosecutors, there was a growing reticence from the Council on deciding on the expansion of the three mines, inspiring great anxiety in members of the community as the end of this daunting participatory process drew near.

There was no possibility, however, to further postpone or abstain from making a decision about mining expansions, and Council members discussed their vote. The discussion started with the presentation of two reports written after visits to the district. The first report [2] shared with Council members was the result of a visit by a sociologist and a historian to the district, as requested by the local prosecutor's office. The prosecutor's office, in addition to sending a letter to the Council, visited the district to gather knowledge about it. The report generated after that visit described the vulnerability of the community in their relationship with the company by mentioning difficulties the community had communicating problems to the company, as well as residents' uncertainty to renovate or make improvements to their houses given the unpredictability of the district's future. Dust, noise, cracks in house walls, and house removal connected with heavy vehicles on local roads were also mentioned, as well as diminished accessibility to some sites, such as the cemetery, and problems with water quality. 
The second assessment was the report by the commission formed by three council members in the visit we had to the area. The text listed changes in the local topography, deforestation, the deterioration of some buildings, the lack of public services, the consequences of heavy vehicles using the area, as well as the inappropriate use of public spaces by the company, such as entrance control on the main road giving access to the district. The report also stated a lack of precise information about the planned expansion of the mines. It pointed out the imminent danger of expanding one of the mines to reach a limit of $500 \mathrm{~m}$ distance from some residences, an act that could amplify existing noise and dust problems, especially given the direction of the wind in the location, blowing from the mine to the village.

The two reports mainly confirmed on paper what residents had previously claimed. However, it was much easier for Council members to vote after reading written summaries, because reports on paper, above all, made members' decision less personal.

All members approved the conclusion by the commission that two of the mines could expand, while the one closest to the urban nucleus could not and neither the company nor the prefecture and prosecutor's office contested that decision. The meeting finished with joy and a sense of achievement for the Council, though discussions on how to improve the quality of life in the community carried on. Council suggestions encompassed making an open contest inviting multi-disciplinary groups to offer ideas on how to revitalize the urban centre of Miguel Burnier.

\section{The aftermath}

After the decision, Miguel Burnier's cityscape still only included a few houses for their population of about 380 residents (even fewer, as the Council did not intervene in up-coming demolitions), a contested list for urban improvements in development (including a new football 
field and professional courses in the face of a shrinking community), and some protected monuments. Still hovering in the background was the fact that dust and noise could possibly worsen, given the mines were to expand, though not as extensively as the company had hoped. These points show that, as much as life quality was discussed in meetings and in the production of reports, the current living conditions in Miguel Burnier were not fully appreciated and contemplated, as demonstrated in a follow-up meeting that took place in December 2013.

On that day, the community leader resigned from the community association and organized a social event for residents, some members of the prefecture, the Council, and the company. At the event, he announced results of his mandate (mainly some festivities and renewal in key constructions almost invariably supported by the company) and mentioned the compromise about the mining expansion. Though this was intended to be a cheerful moment, it did not take long before a resident interrupted the celebration to complain about the dirty water around her house. "I am tired of drinking dirty water", she said. The woman did not get a reply then and soon we all went for dinner. While eating at the very same school where negotiations had started six months before, I struggled to perceive any sense of accomplishment concerning the process and outcome of the negotiations. There certainly was a sense of a job done, the leader had finalized his mandate and negotiations had ended. However, as the woman reminded everyone, the water was still dirty.

The expectation that the Council could remedy power imbalances between a large mining company and a few poor residents was not confirmed. To include residents in the work of cultural heritage is not only to include them in the room but effectively in discussions about the past and future of their place, as well as to open such time horizons by offering first-hand solutions to present concerns. For example, the lack of appreciation for a culturally equipped district happened because cultural heritage was a paradoxical investment amid depopulation, unemployment, poor 
infrastructure, and mining pollution. Cultural heritage was a future (and past) dreamt of by company and Council. Residents, however, did navigate across time and spoke about a past of employment and services in the community when other companies explored the area. To them, the future also looked better elsewhere, and they spoke about moving out (or 'going to heaven'). Thus, when authors discuss the future as a privilege (Souza 2010: 52, Appadurai 2013: 188), there is a missing perspective on how imagining and talking about past and future is part of ordinary life, even more so when the present is so bleak (Baxstrom 2013, Nielsen 2011). In the case of Miguel Burnier, what was missing was the ability to abridge - through participatory meetings disparate views of past, present and future for the district.

Meanwhile, to the community, waiting until the future offered to them by the company would materialize was not only far from ideal, but it also had direct costs in the present: living amid mining pollution. If it is true that real estate companies commonly invest in decayed locations such as Miguel Burnier for profit at a future time (Harms 2013). For current residents who are poor, waiting only makes them poorer (ibid: 356 ) as they do not invest in their properties fearing relocation, but try to sell their homes despite the current low price. This explains why in Miguel Burnier, Ouro Preto or preserved sites in general, looking at decay and seeing a potential for cultural heritage, tourism, and re-population is above all the privilege of those who do not live in the area (Gordillo 2009: 44). The value given to buildings such as the Train Station is a good example of this, as to residents it showed a lack of concern to their relegated lives, while it signals a potential for industrial heritage from afar.

\section{Conclusion}


Mining and cultural heritage have always been connected in Minas Gerais, Brazil. In that region, Ouro Preto stands out as a known example of gold mines’ legacy. Mining in the area, however, never ceased, but shifted from gold to iron and from the city centre to districts in the outskirts, such as Miguel Burnier. That district already accumulated a modern industrial heritage and new mining permits are usually granted based on the maintenance of existing monuments and on the recovery of others.

The compensation of mining with heritage needs to be discussed through different lenses, and I have offered some. The "two-timing rhetoric" (Harms 2011: 119) of "preserving the past for future generations” seen in heritage discussions may undermine pressing problems caused by mining activities in the present. Residents in Miguel Burnier were unable to capitalize on real estate gains that heritage might bring in the future. In the absence of infrastructure works to ameliorate the damage caused by mining, some residents preferred to sell houses at a cheap price in the present. Involving local communities in the discussion of defining what would be a proportional compensation for mining activities was, in this case, no guarantee that those involved were able to truly participate and that their views were taken into consideration. What I observed in Miguel Burnier was thus not a social construction of its past, present, and future, nor the empowerment of residents, a possible outcome of grassroots negotiations. Grassroots meetings, a necessary step to achieve mining permits, were a procedure that on one hand offered space for residents to voice local needs publicly, and on the other hand, restricted their rights to do so in the face of financial dependency and lack of complete information. Participation also divided residents, as they were afraid to negotiate improvements while others set removal deals in the background.

While participation is considered a key democratic contribution in countries such as Brazil, 
in small towns, where people "know each other in a variety of employment and servant relations" (Holston 2008: 276); disputes about rights may not happen through a "direct verbal confrontation” (2008: 277). Holston's findings support my own, and I have shown that the strongest example of confrontation against mining expansion in Miguel Burnier was expressed in writing, as exemplified with the commission's report used to subsidize Council's decisions. Writing made arguments less subjective, inviting for a broader discussion about the role of reports in improving participatory practices.

Improving participatory practices is necessary according to anthropological texts that have epitomized the importance of comprehensive participation to achieve meaningful preservation (Brumann 2009: 295). Yet, what is comprehensive participation remains unclear in a context where people participate in spaces organized by the state (Albert 2016: 13), and look at the state for definitions of both community and participation (Hughes 1998:7; Caldeira and Holston 2005: 406). In such context, future-oriented development policies that could potentially bring a better quality of life and better self-esteem by organizing a troublesome present, and empowering residents, (Nielsen 2011, 2014; Baxstrom 2013) fail to do so, and futures offered were far from those dreamt of by the community.

This study has implications for participatory policies; inviting affected communities to discuss compensatory policies is insufficient to deem a process participatory. Those supposedly empowered to negotiate their own destiny when affected by extreme poverty have an impaired ability to negotiate with potential or current job providers. Effective negotiations would require relaxing immediate internal constraints (Dalton et al. 2016: 179), such as unemployment, and extreme economic dependency. In addition, even those who are not living in the area and as such not affected by extreme internal conditions, such as Council members, failed to appreciate that 
supporting the community would pay off as they saw a threat in their employment situation. This situation resulted in a "low-effort low-outcome" negotiation trap (Dalton et al. 2016).

This being a case where participation was undermining for participants, both in the process of contributing and in the results achieved, there are some lessons to be learned. The company, by sending different delegates to meetings, who spoke as "a passive recipient of the bureaucratic functioning” (Sennett 1976: 331), achieved a level of distance from both Council members and the community helpful for the negotiation of their interests. Even though the community being small and directly affected by negotiations cannot share its residential function with others, the Council, as representatives of diverse areas (Tourism, Environment, Urban Planning, Heritage, Residents Associations) could share mandates with colleagues, instead of having members with a two-year mandate. Shared mandates (secret voting, recorded meetings, published minutes) are strategies that need to be implemented, hopefully, followed by an ethnographer, to evaluate changes in both discussion and outcomes. A second lesson comes from written reports, which proved more effective than open discussions. Written routine practices, such as minutes and reports, often using technical language, are however a paradox in participatory Councils. They may exclude those who do not speak a "bureaucratic language" (Cornwall and Shankland 2013) and yet, at the same time, "protect the legitimate activities (...) from interference, enabling effective governance and representation" (Abram 2017: 39) and for that reason invite for ethnographic appraisals.

While participatory methods improve, slower than the pace of businesses, in the case of Miguel Burnier the district cannot afford delays. As the population shrinks continuously, any improvements that might come will be ineffective for the community who either moved out or cannot make the most a city with buildings empty of people. This demonstrates that waiting has 
disparate consequences for negotiating parties, and participatory practices need to be discussed through a temporal prism.

\section{Notes:}

[1] The Public Prosecutor's Office (Ministério Publico), according to the 1988 Brazil Constitution, article 127, is an organization in charge of "the defence of judicial order, of the democratic regime and of social and individual interests". The prosecutor's office has branches in states and municipalities and the office in Ouro Preto acts, in addition to other areas, in the defence of the environment and the cultural and historic patrimony.

[2] Technical Report (2013) by Minas Gerais Public Prosecutors’ Coordination of inclusion and social mobilization (Coordenadoria de inclusão e mobilização sociais, CIMOS, do Ministério Publico de Minas Gerais) - referring to a technical visit to Miguel Burnier on September 12, 2013, motivated by the Prosecutor of Ouro Preto (Oficio 0650/2013/PJOP). Documents accessed in a visit to CIMOS, Belo Horizonte October 23, 2013. 


\section{References cited}

Abram, S. and Weszkalnys, G. (2013) Elusive Promises: Planning in the Contemporary World. An Introduction. Elusive promises: Planning in the contemporary world, pp.1-33.

Abram, S. (2017). Contradiction in contemporary political life: meeting bureaucracy in Norwegian municipal government. Journal of the Royal Anthropological Institute, 23(S1), 27-44.

Albert, V.A. (2016). The Limits to Citizen Power: participatory democracy and the entanglements of the state. $1^{\text {st }}$ ed. London: Pluto Press.

Appadurai, A. (2013) The future as cultural fact. Essays on the Global Condition. London and New York: Verso.

Avritzer, L. and Costa, S. (2004) Teoria crítica, democracia e esfera pública: concepções e usos na América Latina. Dados Revista de Ciências Sociais 47 (4): 703-728.

Avritzer, L. (2006) New public spheres in Brazil: local democracy and deliberative politics. International Journal of Urban and Regional Research, 30(3), pp.623-637.

(2010) O Estatuto da Cidade e a democratização das políticas urbanas no Brasil. Revista Crítica de Ciências Sociais, (91), pp.205-221.

(2012a) The different designs of public participation in Brazil: deliberation, power sharing and public ratification. Critical Policy Studies, 6(2), pp.113-127.

(2012b) Sociedade civil e Estado no Brasil: da autonomia à interdependência política. Opinião Pública, 18(2), pp.383-398.

Aykan, B. (2013). How participatory is participatory heritage management? The politics of safeguarding the Alevi Semah ritual as intangible heritage. International Journal of Cultural Property, 20(4), 381-405.

Barbalet, J. (2009). A characterization of trust, and its consequences. Theory and society, 38(4), 367382.

Baxstrom, R. (2013) Even governmentality begins as an image: Institutional planning in Kuala Lumpur.” In Abram Sand Weszkalnys G (eds) Elusive Promises: Planning in the Contemporary World. New York: Berghahn Books, pp.137-153.

Brumann, C. (2009) Outside the glass case: the social life of urban heritage in Kyoto. American Ethnologist, 36(2), pp.276-299.

Caldeira, T. and Holston, J. (2007) State and urban space in Brazil: From modernist planning to democratic interventions. In Ong A and Collier S (eds) Global assemblages: Technology, politics, and ethics as anthropological problems. London: Blackwell, pp.393-416. 
Chuva, M.R.R. (2009) Os arquitetos da memória: sociogênese das práticas de preservação do patrimônio cultural no Brasil (anos 1930-1940). Rio de Janeiro: Editora UFRJ.

Cornwall, A. (2008) Deliberating democracy: scenes from a Brazilian municipal health council. Politics \& Society, 36(4), pp.508-531.

Cornwall, A. and Shankland, A. (2013) Cultures of politics, spaces of power: contextualizing Brazilian experiences of participation. Journal of Political Power, 6(2), pp.309-333.

Costa, E.B.D. (2011) Totalidade urbana e totalidade-mundo. As cidades coloniais barrocas face à patrimonialização global (Doctoral dissertation, Universidade de São Paulo).

Dalton, P.S., Ghosal, S. and Mani, A. (2016) Poverty and aspirations failure. The Economic Journal, 126(590), pp.165-188.

[anonymized]

Gledhill, J. (2013) Redeeming the promise of inclusion in the neo-liberal city: grassroots contention in Salvador, Bahia, Brazil.” In Abram Sand Weszkalnys G (eds) Elusive Promises: Planning in the Contemporary World. New York: Berghahn Books, pp.117-135.

Gordillo, G. (2009) The ruins of ruins: on the preservation and destruction of historical sites in northern Argentina. Ethnographies and archaeologies: iterations of the past. Gainesville: University Press of Florida, pp.30-54.

. (2013) Bringing a place in ruins back to life. Reclaiming archaeology: beyond the tropes of modernity, pp.323-336.

Guareschi, P.A. and Jovchelovitch, S. (2004) Participation, health and the development of community resources in Southern Brazil. Journal of Health Psychology, 9(2), pp.311-322.

Harms, E. (2013) Eviction time in the new Saigon: Temporalities of displacement in the rubble of development. Cultural Anthropology, 28(2), pp.344-368.

(2011) Saigon's Edge: On the Margins of Ho Chi Minh City. University of Minnesota

Press.

Heathcott, J. (2013) Heritage in the dynamic city: The politics and practice of urban conservation on the Swahili coast.International Journal of Urban and Regional Research, 37(1), pp.215-237.

Holston, J. (2008) Insurgent citizenship: Disjunctions of democracy and modernity in Brazil. Princeton University Press.

Hughes, G. (1998) Understanding crime prevention, social control, risk and late modernity. Maidenhead: Open University Press. 
IBGE Instituto Brasileiro de Geografia e Estatística (2017) Cidades: Ouro Preto http://cidades.ibge.gov.br/xtras/perfil.php?lang=\&codmun=314610\&search=minas-gerais|ouropreto|infograficos:-informacoes-completas (accessed 25 July 2018).

(2012) Perfil dos Municipios Brasileiros. Available at: ftp://ftp.ibge.gov.br/Perfil_Municipios/2012/munic2012.pdf (accessed 1 October 2015).

Jovchelovitch, S. (1995) Social representations in and of the public sphere: towards a theoretical articulation. Journal for the theory of social behaviour, 25(1), pp.81-102.

Koster, M. and Nuijten, M. (2012) From preamble to post- project frustrations: the shaping of a slum upgrading project in Recife, Brazil. Antipode, 44(1), pp.175-196.

Larkin, B. (2013). The politics and poetics of infrastructure. Annual review of anthropology, 42, 327343.

Lombard, M. (2013) Citizen Participation in Urban Governance in the Context of Democratization: Evidence from Low- Income Neighbourhoods in Mexico. International Journal of Urban and Regional Research, 37(1), pp.135-150.

Marks, M. and Bonnin, D. (2010) Generating safety from below: community safety groups and the policing nexus in Durban. South African review of sociology, 41(1), pp.56-77.

Neves, M.D. (2012) O rodeadouro da Itatiaia: dos bandeirantes aos inconfidentes. In Baeta, A. and Pilo H. (eds) Miguel Burnier: Marcas Históricas. 1st ed. Belo Horizonte: Gerdau, pp.28-79.

Nielsen, M. (2011) Futures within: Reversible time and house-building in Maputo, Mozambique. Anthropological Theory,11(4), pp.397-423.

(2014) A wedge of time: futures in the present and presents without futures in Maputo, Mozambique. Journal of the Royal Anthropological Institute, 20, pp.166-182.

Penha, U. C. (2012) Miguel Burnier: Geologia e paisagens”. In Baeta, A. and Pilo H. (eds) Miguel Burnier: Marcas Históricas. 1st ed. Belo Horizonte: Gerdau, pp.13-27.

Portal do Turismo de Ouro Preto (2014) Dados geográficos Available at: http://www.ouropreto.mg.gov.br/portal_do_turismo_2014/dados-geograficos (accessed 18 October 18 2015).

Prefeitura Municipal de Ouro Preto (2007) Invetario do Distrito de Miguel Burnier. Ouro Preto: Prefeitura Municipal de Ouro Preto.

(n.d.). Mapa Ouro Preto. Image Available at: http://www.ouropreto.mg.gov.br/patrimonio/imagens/mapaop.png (accessed 8 December 2015). 
Raco, M., Henderson, S. and Bowlby, S. (2008) Changing times, changing places: urban development and the politics of space-time. Environment and Planning A, 40(11), pp.2652-2673.

Raco, M., Durrant, D., \& Livingstone, N. (2018). Slow cities, urban politics and the temporalities of planning: Lessons from London. Environment and Planning C: Politics and Space, 36(7), 11761194.

Reed, A. (2002) City of details: interpreting the personality of London. Journal of the Royal Anthropological Institute, 8(1), pp.127-141.

Ribeiro, R.W. (2007) Paisagem cultural e patrimônio. 1st ed. Rio de Janeiro: IPHAN.

Rodrik, D. (2006). Goodbye Washington consensus, hello Washington confusion? A review of the World Bank's economic growth in the 1990s: learning from a decade of reform. Journal of Economic literature, 44(4), 973-987.

Sennett, R. (1976) The fall of public man. 1st ed. Cambridge: Cambridge University Press.

Silverman, H. (2002) Touring ancient times: the present and presented past in contemporary Peru. American Anthropologist, 104(3), pp.881-902.

Souza, J. (2010) Os Batalhadores Brasileiros: Nova Classe Média ou Nova Classe Trabalhadora? 1st ed. Belo Horizonte: Editora UFMG. 